\title{
Kai hea kai hea te pū o te mate? Reclaiming the power of pūrākau ${ }^{1}$
}

\author{
ROBERT POUWHARE
}

\begin{abstract}
The pūrākau our ancestors told about the universe and our place within it have been bowdlerised through the process of colonisation. These narratives, as they were transmitted over generations, were transformed by the European settlers, missionaries and educators, from 'myths' - oral traditions imbued with the power of the sacred - into 'fables' and 'folktales'. As such, they have largely been neutered of their epistemological power, and their role in sustaining our culture has been substantially diminished. For example, in its original iterations, the ancient story of Māui in which his quest for immortality was foiled by the Tirrairaka contained a fundamental lesson: Māui dies in the act of penetrating Hinenui-te-pō; from the sex act comes both new life and the sure knowledge of mortality; women are a source of power, life and death. In translation, this story was sanitised; in particular, the description of Māui's fatal entrance as a lizard into Hine-nui-tepō's vagina, were euphemised and displaced, shifted to less controversial body parts. In my paper and presentation, I propose strategies for restoring the power of performance of our pūrākau through the reclamation of the act of storytelling in diverse media. In making new platforms for performing these old stories, we can revitalise the Reo and tikanga, and in so
\end{abstract}

Portions of this paper were developed from materials originally presented in my MPhil thesis: He iti te manu he nui te kōrero (AUT 2016). 
doing reconnect ourselves and our young people to the world that our tippuna created.

\section{Introduction}

Kai hea, kai hea te pū o te mate?

Kai runga

Kai raro

Kai te hikahika nui o Hine-nui-te-pō!

Where, where is the source of death?

It is above

it is below

It is in the organ of Hine-nui-te-pō!

My first encounter with this Māui story was at traditional Ngāti Haka Patuheuheu Tūhoe tribal wānanga that were held at Waiōhau marae in the late 1960s and early 1970s. These wānanga were designed to acquaint younger hapū members with the history of the clan and the tribe. The recounting of the stories orally were spectacles in themselves. The listeners were absorbed into what was thought to be a simple story about a bird who appeared to be cheeky, mischievous and disobedient, a bird that made peculiar sounds and squeaks, and the birdsong and its dance were re-enacted to demonstrate tīrairaka's prowess at flight and quick movement. The audience was instructed to study carefully the movements of the fantail which revealed the rudimentaries of all the military movements associated with Māori weaponary and warfare. These manouvres could also be witnessed in the actions of the haka and the wero (the challenge of a warrior). Observations of the bird in action and its flight confirmed tìrairaka's prowess at aerodynamics as it appeared to change direction in mid flight.

The tribal diaspora has impacted on the traditional transmission of knowledge to tribal members. Few are now 
exposed to the wānanga of my youth. Instead there is a reliance on written accounts that 'standardise' Māori oral traditions and do not take cognisance of the variations, such as the different tribal accounts of the Māui traditions. The metaphysical world of the Māori is a complex and multi-faceted reality that has been ill-served by such standarisations. The Māori experience of the transition from oral to written storytelling in the Māori experience resonates with Walter Benjamin's (2007) despair with the demise of the storyteller in European society as a result of industrialisation. In 'The Storyteller,' Benjamin describes traditional pre-industrialised European storytelling as a community-based performance practice reminiscent of my own Ngāti Haka Patuheuheu tribal wānanga. He identifies and critiques the advent of the printing press as the harbinger of the demise of storytelling (as performance). For Benjamin, the novel - like written accounts of Māori knowledge - can be seen to turn the inter-generalional communality of oral traditions into individualistic pursuits:

...the birthplace of the novel is the solitary
individual, who is no longer able to express himself
by giving examples of his most important
concerns, is himself uncounseled and cannot
counsel others. (Benjamin, 2007, p.87)

The novel does not require an audience for the storyteller to interact; it transforms the shared act of speaking, listening and debating communal values into a solitary pastime, from something enacted - performed - to something passively received.

The development of the app He iti te manu he nui te kōrero: The bird is small the story is epic represents my attempt to reconcile the collective and individual dichotomy of postindustrialisation storytelling by harnessing the power of technology to revitalise Māori traditional language and knowledge. The screening of the app encourages the audience 
to engage actively in the experience of storytelling. Storytelling in this way promotes discussion, not least because of the provocative content. There are ancient words such as puapua (the outer lips of the vagina) that have been included to extend the vocabulary of fluent speakers. As such, it is designed also to expose second language learners to ancient words embedded in Māori cultural traditions.

While the app embraces the new technology and the learning is multifaceted, its development is driven by concerns about the continuing decline in the Māori language. ${ }^{2}$ Ngugi Wa Thiong'o (1986), a Nigerian intellectual, is famous for having abandoned using English as the primary language of his work in favour of Gikuyu, his native tongue. This act was based on a conscious decision to define the world in his own terms, shaped by a Gikuyu worldview. Similarly, this app has been designed using te Reo Māori and, in so doing, deliberately shaped by the Māori world view.

The app is based on a story the old people told: a simple and elegant explanation of death. It was the use of te Reo, of words that were onomatopoeic, of phrases that mimicked the bird the sound effects and psycho-acoustics - that entranced and entertained the audience. A bird, although small in stature carries a massive story: Tìraiaraka flies with a wealth of history, knowledge and power on the tip of its wings and fantail.

\section{Reconnecting to the power of pūrākau}

Lee (2009) defines pūrākau as:

...a traditional form of Māori narrative, (that) contains philosophical thought, epistemological constructs, cultural codes, and worldviews that are fundamental to our identity as Māori. Pūrākau

Statistics NZ 2013 reported a 4.5\% decrease in the number of Māori speakers compared to the 2006 Census data.

Te Kaharoa, Special Edition, Ka Haka - Empowering Performance: Māori and Indigenous Performance Studies Symposium, vol. 9, 2016, 
are a collection of traditional oral narratives that should not only be protected, but are understood as a pedagogical-based anthology of literature that is still relevant today. ( $\mathrm{p} 1)$

The central narrative in the story adapted for the app is the quest by Māui for immortality, everlasting life for humans. It involves three protagonists: Mâui the demi-god; his friend Tirairaka, the fantail who ultimately causes the disastrous denouement of the story; and Hine-nui-te-pō, the Great Goddess of Death. The story begins with Māui enquiring of his mother: where is the genesis of death? He is told to seek his ancestress Hine-nui-te-pō as she holds the key to eternal life. He gathers his friends the birds and, in particular, Tirairaka, who accompany him on this his last adventure. Before approaching the slumbering Goddess, he warns his companions they are not to make any noise, no chattering or laughing. Only after he emerges out of her mouth will they be permitted to make a sound. As he gets closer, Māui the supranatural, Māui the demi-man, demi-god, Māui the possessor of magical powers, changes his shape yet again. This time he metamorphoses into a lizard (mokomoko). (Some say a hairy lizard.) As a mokomoko he slithers closer to the sleeping beauty, to gain admittance into the body of Hine-nui-te-pō via her vagina. If he can travel through her body and emerge through her mouth, he will succeed in gaining immortality and, as a consequence, reverse the birthing process.

The birds perched in the boughs of the tree look down in astonishment. Mokomoko creeps ever so closer to Hine-nui-tepō's slightly parted thighs all the time sniffing and savouring the perfume that emanates from her body. He makes the final approach, honing in on her puapua (the outer lips of her vagina). He gingerly climbs up, taking care not to wake her, and slowly but surely inserts his head into the sacred portals. The temerity of Māui so astounds Tirairaka that, with only half of Māui's body inserted into her vagina and the tail remaining on 
the outer of her organ, the fantail can no longer restrain himself and erupts into raucous laughter. The rambunctious cacophony startles Hine-nui-te-pō and she awakes to feel some hairy member penetrating her most sacred orifice. "Who is this treacherous demon that dares to invade me?" she thunders. Realising that most of mokomoko has disappeared deep into her vagina, and horrified, she summons up all her power and the forces of the universe to lacerate, slash, crush and destroy the interloper within her vagina - killing mokomoko/Māui instantly. Thus, in a cataclysmic orgasm of destruction, Māui's attempt to conquer his prey and to overcome death was thwarted, and humanity's fate was sealed forever.

Humans are destined to die. Immortality became out of reach the moment mokomoko/Māui entered her vagina and was crushed. Indeed, humans are continually reminded of the enormous power of women who not only give birth to humans and nurture them throughout their lives. But for Māori it is Hine-nui-te-pō, the Great Goddess of Death, who stands at the gateway to the underworld to receive and console us when we die.

\section{Mythological Messages}

Pūrākau are the mythologies, the ancient oral narratives of the Māori people. These stories represent an attempt by the ancestors to explain phenomenon and ponder the great mysteries for all humanity: life, death, sky, earth, space, and the universe. These explorations seek to explain who we are, where we are from, why we do things the way we do and how we organise ourselves with an eye to both past and future. Ranginui Walker (1990) posits that these mythologies are carefully arranged as complexes of narratives, beginning with the Creation Story and located in the remote past. These are stories of the cosmogony in which Māori described the phenomenological world into distinct divisions of existence: genealogical recitations of the state of Te Kore (the void), Te Pō

Te Kaharoa, Special Edition, Ka Haka - Empowering Performance: Māori and Indigenous Performance Studies Symposium, vol. 9, 2016, 
(the dark) and Te Ao Mārama (the world of light) - epochs of time and the expansion of space.

Ko Te Kore te whiwhia

Ko Te Kore te rawea

The Void where nothing is possessed

The Void where nothing is felt

Ko Te Pō nui

Ko Te Pō roa

Ko Te Pō uriuri

The Great Night

The Long Night

The Deep Dark Night

Ki Te Whai Ao

Ki Te Ao mārama

To the first glimmer of Light

To the bright of Day

The primal parents Ranginui (Sky Father) and Papatūānuku (Earth Mother) are at the epicentre of this whakapapa (genealogy) darkness and light. Their offspring, the gods, were trapped within their tight embrace. They planned and battled to prise the parents apart to open up the world and universe and allow light and potential to develop. Walker (1990) further explains that embedded within these narratives are 'myth- messages': a blueprint, a charter upon which Māori social organisation is predicated.

The second complex of stories, my focus here, are concerned with the entrepreneurial endeavours of Māui, the demi-god who embarks on a series of hazardous journeys. He challenges convention and ultimately ends his life and that of all humans, in a spectacular collision between the labia of Hine-nui-te-pō (the Great Goddess of Death). 


\author{
Ka kukuti ka kukuti \\ Ngā puapua o Hine-nui-te-pō \\ The vulva of Hine-nui-te-pō \\ Contracted and constricted
}

The third set of pūrākau are about the union of a celestial being, the divine Hāpai, who descended from the heavens to cohabit with the handsome aristocrat Täwhaki the grandson of the cannibalistic Whaitiri. His father Hema trespasses on the lands of the Ponaturi the evil beings and is blinded and killed by them. On giving birth to a daughter Hāpai was so deeply wounded by a derogatory remark Tāwhaki made about their child that she resolved to leave her earthly husband and return to the tenth heaven where she was from. The remorseful Tāwhaki mourned for his beautiful wife and set forth to join her in the heavens of the divine ones by climbing a vine.

\author{
Piki ake Tāwhaki \\ Ki te rangi tuatahi \\ $\mathrm{Ki}$ te rangi tuarua... \\ Ascend on high Tāwhaki \\ To the first heaven \\ To the second heaven...
}

Simpson and Roud (2000) define myth as "stories about divine beings, generally arranged in a coherent system; that are revered as true and sacred". Etymologically the word myth may be traced to the French mythe (1818) the Latin mythus and the Greek mythos and in general means speech, thought, story or anything delivered by word of mouth (Harper, 2001). Harper also claims that only from 1840 onwards, the general sense of mythology came to mean "untrue story or rumour." I contend that this denigration of the true essence of mythology to "myth" coincides with the colonial experience in New Zealand, as the settler government set about establishing the apparatus of the state with its various agencies of power and domination vis-a- 
vis the education system, displacing and censoring Māori mythologies. This process, when colonisation was at its zenith, systematically undermined traditional beliefs and practices, corrupting and marginalising cultural narratives as "puerile folk stories", even claiming they were "works of the devil" (McLintock 1966).

By the time the British arrived on these shores, they were well practised at the science of colonisation as they had huge success in their major forays in the sub-continent of India the Americas and Africa. Frantz Fanon (1976), conceivably the most influential Black decolonization theorist and philosopher of the twentieth century, harnessed the shared experience of oppression, precipitated a deluge of indigenous discourses on the subject, and galvanized indigenous people to challenge colonialism. Before Fanon, colonisation was seen more simply as a process of dispossession. This process involved the alienation of the native peoples from their natural resources (land), produced social and cultural disruption, and invariably impoverishment. The psychological ramifications of colonisation remained uncharted territory until Fanon, a French trained psychiatrist, linked psychiatric disorders amongst Algerians with their fight for independence from their colonisers, the French. In The Wretched of the Earth, he shows how colonised peoples in different parts of the world share the common psychological disorders and makes a case for the psychopathy of colonisation.

Fanon is particularly scathing of the role of Christian churches in the colonisation process. He says:

But the triumphant communiqués from the missions are in fact a source of information concerning the implantation of foreign influences in the core of the colonized people. I speak of the Christian religion, and no one need be astonished. The Church in the colonies is the white peoples Church, the foreigners Church. She does not call the native to God's ways, but to the ways of the 
white man, of the master, of the oppressor. And as we know, in this matter many are called but few are chosen (p.63).

Fanon's thesis that the Church in the colonies is a powerful tool in terms of the psychological indoctrination inspired Ngugi Wa Thiong'o (1986) to develop his theory of 'decolonising the mind', which is also the title of his most well-known work. Thiong'o tells us that the juggernaut, the force that was colonization, was hellbent on civilising the savages. In Aotearoa, the annihilation of Māori cultural norms was effected by replacing them with Eurocentric values. Even the Māori language was described variously as been 'barked' 'screeched' and 'grunted' as a way of denouncing Māori as being less than human.

A community's language is a unique part of their culture, often connecting them with their ancestors or with the land, making up an essential part of their history and how they see themselves. The Tejano poet Gloria Anzaldúa, eloquently captures the inextricability of language, culture and identity, when she tells us: "Ethnic identity is twin skin to linguistic identity - I am my language. Until I take pride in my language I cannot take pride in myself" (2003, p. 159). In Thiong'o' view, decolonization is revitalisation of cultural knowledge. As such, it challenges the power imbalance between the colonised and the colonisers. Decolonization of the mind requires dispensing with colonialising filters to reclaim tūturu (authentic) Māori values, beliefs and practices. This quest for authenticity demands a consideration of the bowdlerization of Māori knowledge.

\section{Bowdlerisation of Māori knowledge}

The term to bowdlerise can be traced to the British doctor and 'philanthropist' Thomas Bowdler (1754 - 1825), who published the first edition of The Family Shakespeare in 1820. His purpose was to censor Shakespeare's work so that it would be suitable 
for women and children, and thereby preserve Victorian family values. As a result of Bowdler's vandalism of Shakespeare the word bowdlerism became synonymous with the censorship of words or images deemed, indecent, offensive or licentious. To bowdlerise is to modify passages considered vulgar and changed for fear of offending finer sensibilities and, in so doing, to mask and dilute the original meanings.

The concept of bowdlerisation is one I have adopted to describe the sanitisation of these ancient narratives. Interestingly, bowdlerisation is evident even in the sanitized scriptures of the Old Testament, where euphemisms are used, as with, for example the phrase 'to cover one's feet' to refer to lowering one's garment to urinate or defecate (Feldman, 1993:193).

When he was gone out, his servants came; and
when they saw that, behold, the doors of the parlor
were locked, they said, Surely he covers his feet in
his summer chamber (Judges 3:24, emphasis
mine).

Similarly, in the Victorian age, more than a few writers, educators and commentators could not quite bring themselves around to use the word 'vagina'. The hangover from Victorian moralities continue to pollute the modern day versions of our stories, so that our children remain confused as to what part of the anatomy killed Māui in his quest for immortality. Worse it creates the idea that the human body and natural bodily functions are offensive.

ka kukuti ka kukuti ngā puapua o Hine-nui-tepō...

slashed and lacerated by the pudenda muliebria of Hine-nui-te-pō... 
The early ethnographer, Elsdon Best (1996) deliberately used the Latin pudenda muliebria (p.947) to describe Hine-nuite-pō's genitalia. It translates archaically but unhelpfully, as 'skirts of women' - a euphemism for vagina. When used figuratively, pudenda take on another meaning as a shameful part of something. The idea of sanitising cosmological narratives, goes to the very heart of this paper. Many early renditions of the story of Maui's quest for immortality and his fatal encounter with Hine-nui-te-pō, bowdlerized, fall far short of revealing the entire narrative and its significance.

\section{Traditional Knowledge as Performance}

Again, my thoughts turn to the way I was taught this particular pūrākau and reflect on the way traditional knowledge was passed down to successive generations in a tribal setting. When I was a young child, we lived in a remote village in the Urewera where there were barely roads, no electricity and just a flicker of radio. At night, our grandparents would sing ancient waiata. Some of this sung poetry retold ancient histories and for them, the contemporary battles against the white man, the evil colonisers who came to steal our land. As youngsters we had no understanding what the chants meant. All we wanted to do was sleep. But through the power of repetition, the old people would drill this information into our brains even when we were in deep sleep. It was not until I grew up that I understood that the oriori (lullabies) were designed to inculcate tribal history, to educate us enduringly about tribal trajectories, ancient hostilities and enmities. I now understand that this was an ancient pedagogy, a way of ensuring the transmission of knowledge through time.

Mazer (2011) observes that performance in Kapa Haka is a powerful and provocative vehicle to assert resistance, mana and identity. Her observations of these performances at Te Matatini confirm the nexus between performance, competition, pride, identity and transmission of information and knowledge. 


\begin{abstract}
At Te Matatini there is a strong sense that each iwi is performing its identity as iwi at the same time that it is performing its definition of what it means to be Māori for everyone else. The bodies and actions of the performers are focused on performative affirmation: "This is who we are, and we know who we are because this is what we do; we act now as our ancestors did before us, moving and singing together in groups, not as individuals, united in spirit and unified in form." Taken as a whole, then, the Kapa Haka performance evokes an idealisation of community.... It makes for performers and audiences alike a reification of Maori communality and collective identity. (p.43)
\end{abstract}

This sung poetry, these incantations and mōteatea chanted in monotone, these carefully choreographed haka all conspire to tell a story. The poly-vocality is finely nuanced so that it takes a practiced eye to decipher the overt and covert messages contained in the powerful performances and storytelling. According to an ancient Native American proverb: 'It takes a thousand voices to tell a single story' (Tell your story add your voice n.d.). When there are a thousand performers all giving voice to the same story, as audiences and participants in this drama, we are left exhausted but convinced of each kapa's truth and story.

\title{
Digital Storytelling
}

Story telling was an art perfected by the tohunga and, arguably, is the original form of teaching (Pedersen, 1995). Whilst storytelling is not new, digital storytelling is (Meadows, 2003). For Sadik (2008), digital storytelling provides a meaningful technology-integrated approach for engaged learning. In fact, there is growing evidence that digital storytelling captures imagination and elevates the educational experience for both 
learners and teachers (Robin, 2008: Keiha, Moorfield, Ka'ai \& Spooner, 2008). We are becoming dependent on technology to enhance our learning experiences. To that end, Keiha, Moorfield, Ka'ai \& Spooner (2008) provide compelling evidence to support the claim that the introduction of an integrated digital language learning strategy can significantly improve engagement and learning experiences. Those who participated in the study also reported increased satisfaction in the learning process.

The application of digital storytelling is an essential tool in the struggle to present Māori culture and language meaningfully to a new technologically savvy generation. I have already alluded to the impact of the colonial experience on the demise of language and cultural knowledge. According to Durie (2006), Te Reo Māori is vital to health and wellbeing of the indigenous people of Aotearoa. The loss of language has psychological repercussions because language is integral to collective and personal identity (Johnson 2009; Lambert 1972; Liebkind 1999). Banse (2012) contends that the panacea to halt language erosion could well be technology. To ensure Māori are not disinherited calls for innovation of ancient idioms in ways that will resonate with the younger generation.

Māori language and culture is inclusive. Non-Māori New Zealanders can, and should, also be encouraged to be an integral part of the revitalisation of te Reo me ngā tikanga Māori. 'Using digital technologies to create and access our distinctive cultural content enhances our identity as New Zealanders' (NZ Digital Strategy, 2008). Digital, interactive publications in te Reo are operating at the vanguard of contemporary language revitalisation efforts. To this end Tangata Whenua HD Ltd produced three interactive apps. ${ }^{3}$ Tieke, Mokomoko, and He wai te kai! were commissioned by the Ministry of Education in 2013. The purpose of the apps was to improve Māori students' engagement in literacy, maths and science. These apps won the

3 These are interactive apps written by Robert Pouwhare.

Te Kaharoa, Special Edition, Ka Haka - Empowering Performance: Māori and Indigenous Performance Studies Symposium, vol. 9, 2016, 
Microsoft Award for Technology in the Taurawhiri Māori Language Awards 2013. The interactive component of the apps brings another dimension to storytelling that can be described as performance. Anecdotally, students who use the apps are most likely to do so in small groups. In this sense they form small communities, and in doing so restore an old sense of communality in this new mode. These apps are the precursors to a series of sophisticated pūrākau that I am in the process of developing.

\section{Conclusion}

This paper has argued for the reclamation of the power of pūrākau as sources of sacred knowledge. I have demonstrated how pūrākau re-presents these mythologies and cosmogonies as a decolonizing instrument and in the process centres our mind-set, our headspace deep within Māori epistemology. Pūrākau in this state conscientiously brought together ancient beliefs, archaic words, best performed to the rhythm of everyday tribal life. In that setting, the storytelling enchantingly, hypnotically conspired with the cadences of the Reo to lure the unwary to sleep. Mercifully, Māori belief in repetition and the power of the subconscious to learn meant that no one was left ignorant. This unassuming setting can be described as real life theatre.

Frantz Fanon (1975) described traditional tribal lifeways as '...a world under different skies.' Sadly, it is now impossible to replicate the tribal wānanga learning of y youth in its truest form - as performance. However, I have also argued that pūrākau can be adapted to the $21^{\text {st }}$ century to preserve the language. The effort to resist language loss is the impetus for all of my work and informs the development of the pūrākau series of apps. Therefore, the pūrākau apps that I have produced are embedded in Māori language to engage the audience in the art of tūturu (authentic traditional) storytelling using modern technology. This retains the 'performance' element of pūrākau 
that is integral to the survival of Māori language and culture. Language revitalization frames this paper, which captures the larger struggle for personal and communal well-being, the selfdetermination and cultural survival of my people. 


\section{References}

Anzaldúa, G. (2003). La Conciencia de la Mestiza: Towards a New Consciousness. In C. McCann \& K. Seung-Kyung (Eds.), Feminist Theory Reader: Local and Global Perspectives, New York, NY, Routledge.

Banse, T. (2012, March 19). Digital technologies give dying languages new life (Radio Broadcast). Auckland: Radio New Zealand.

Best. E. (1996). Tuhoe, The Children of the Mist. Wellington: Reed Publishing.

Benjamin, W. (2007). The Storyteller. Iluminations. Translator Harry Zohn. 1968. New York: Schocken.

Bowdler, T. (2009). The Family Shakespeare. Oxford: Routledge. Taylor and Francis Group.

Durie, M. (2006). Measuring Māori wellbeing. New Zealand Treasury Guest Lecture Series, 1.

Feldman, L.H. (1993). Josephus's Portrait of Ehud. In J. C. Reeves \& J. Kempen (Eds). Pursuing the Text: Studies in Honor of Ben Zion Wacholder on the Occasion of his Seventieth Birthday. Sheffield: Sheffield Academic Press.

Fanon, F. (1976). The Wretched of the Earth. New York: Grove Press. Harper, D. (2001). Online Etymology Dictionary. http://www.etymonline.com/

Keiha, P., Moorfield, J., Ka'ai, T. \& Spooner, H. (2008). Advancing a Digital Strategy for Learning and Teaching Te Reo Māori. Wellington: Ako Aotearoa. https://akoaotearoa.ac.nz/akohub/good-practice-publication-grantsebook/resources/pages/advancing-digital-strategy-learning

Johnson, K. (2009). Second Language Teacher Education: A Sociocultural Perspective. New York: Routledge.

Lee, J. (2009). Decolonising Māori Narratives: Pūrākau as a Method. MAI Review, 2(3), pp. 79-91.

Lambert, W. (1972). A social psychology of bilingualism. In IA.S. Dil (Ed.) Language, Psychology and Culture. Essays by Wallace E. Lambert. Stanford. CA: Stanford University Press, pp: 212-235. Liebkind, K. (1999). Social psychology. J. A Fishman (Ed). Language and Ethnic Identity. Oxford: Oxford University Press, pp.141-151. Mazer, S. (2011). Performing Māori: Kapa Haka on the Stage and on the Ground. Popular Entertainment Studies, 2(1), pp. 41-53.

McLintock, A. H. (1966). Encyclopaedia of New Zealand. Wellington: Government Printer. 
Meadows, D. (2003). Digital storytelling: Research-based practice in new media. Visual Communication, 2(2), 189-193.

Ngugi Wa Thiong'o. (1986). Decolonising the Mind: The politics of language in African Literature. New Hampshire: Heinemann.

Pedersen, E. (1995). Storytelling and the art of teaching. English Teaching Forum. Vol. 33. No. 1. P.2-5.

Robin, B. R. (2008). Digital storytelling: A powerful technology tool for the 21 st century classroom. Theory into practice, 47(3), 220-228.

Sadik, A. (2008). Digital storytelling: A meaningful technologyintegrated approach for engaged student learning. Educational technology research and development, 56(4), 487-506.

Simpson, J. \& Roud, S. (2000). Dictionary of English folkore. Oxford, UK: Oxford University Press.

Statistics NZ. (2013). Census QuicksStats about Māori.

http://www.stats.govt.nz/Census/2013-census/profile-andsummary-reports/quickstats-about-maori-english/maorilanguage.aspx

Tell your story add your voice (n.d.) Retrieved from http://www.nrcprograms.org/site/PageServer?pagename=Thousa ndVoices home

Walker, R. (1990). Ka Whawhai Tonu Mātou: Struggle Without End. Auckland: Penguin Group.

Robert Pouwhare is Tūhoe and a fluent speaker of the Ngāti Haka dialect. He is a Māori language revivalist and has been politically active for forty years agitating for the retention, maintenance and survival of the Māori reo and tikanga. He was recruited by Ngā Tamatoa and Te Reo Māori Society in the 1970s to apply for a television producer/directors course with the state broadcaster and subsequently was part of a team that introduced the first dedicated Māori television programme Koha in 1980. The political agenda of these groups was to force the government by way of a petition, demanding the inclusion of Māori language into the education system and to target broadcasting with the view of setting up a separate television channel. Over the past decades Robert has produced and 
directed hundreds of hours of Māori language television programmes for state and Māori Television. He is dedicated to language revitalisation and continues to conceptualise new ways to engaging young Māori to learn the language through digital technology. His latest foray to inveigle young minds was the production of three apps aimed at increasing engagement of Māori children with literacy, numeracy and science. He is currently teaching at AUT in Māori media and Māori language. 